\title{
Mortality rates from a Nigerian isolate of the Infectious Bursa Disease Virus and passive haemagglutination antibody titer that protects chicks against challenge with the virus isolate
}

\author{
Maduike C. O. Ezeibe ${ }^{1 *}$, John O. A. Okoye ${ }^{2}$, Temitope M. Ogunniran ${ }^{1}$, Paul C. Animoke $^{1}$, \\ ljeoma J. Mbuko ${ }^{1}$, ljeoma A. Nwankwo ${ }^{1}$, Augustine A. Ngene ${ }^{1}$ \\ ${ }^{1}$ Department of Veterinary Medicine, University of Nigeria, Nsukka, Nigeria; ${ }^{*}$ Corresponding Author: maduikeezeibe@yahoo.com \\ ${ }^{2}$ Department of Veterinary Microbiology and Pathology, University of Nigeria, Nsukka, Nigeria
}

Received 28 April 2013; revised 29 May 2013; accepted 15 June 2013

Copyright (C) 2013 Maduike C. O. Ezeibe et al. This is an open access article distributed under the Creative Commons Attribution License, which permits unrestricted use, distribution, and reproduction in any medium, provided the original work is properly cited.

\begin{abstract}
To determine passive haemagglutination (PHA) antibody titer that would protect chicks against Nigerian isolates of the Infectious Bursa Disease Virus (IBDV), five groups of chicks aged $\mathbf{3 0}$ days which had different antibody titers were challenged with a Nigerian isolate of virulent IBDV. Mortality rates of the different groups were plotted against their respective mean PHA antibody titers. A group with zero antibody titer had a mortality rate of $75 \%$ while those with PHA antibody titers of 185.6, 243.2, 256 and 307.2 had mortality rates of $40 \%$, zero, zero and zero respectively. Linear equation generated for a line of best fit of the graph of mortality rates of the chicks on their IBD antibody titers gave antibody titer $(X)$ at which mortality $(Y)$ would be zero as 300 . A mortality of $75 \%$ and the high antibody level needed to protect chicks suggest that the isolate may be a hypervirulent strain.
\end{abstract}

Keywords: Protective Antibody Titer; Hypervirulent Infectious Bursa Disease Virus Strain; Nigerian Isolate

\section{INTRODUCTION}

Infectious Bursa Disease (IBD) is an acute, highly contagious viral disease of young chickens. The virus attacks primarily lymphoid cells, especially B-cells. Lymphoid tissues of the cloacal bursa are most severely affected [1].

Clinical signs of IBD in chicks include ruffled feathers, trembling, depression, diarrhea, pecking of the vent. Fever starts 48 hours post infection but body temperature drops below normal just before death. The disease runs its full course in about 7 days [2-7].

In fully susceptible flocks, IBD appears suddenly and there is a high morbidity rate. Mortality in IBD may be nil but can be as high as $20 \%$ - $30 \%$, usually beginning on the third day of onset of clinical signs and peaking and receding in a period of 5 - 7 days.

Initial outbreaks on a farm are usually the most acute. Recurrent outbreaks in succeeding broods are less severe and frequently go undetected. Many IBDV infections are silent, owing to age of birds (less than 3 weeks old or above 12 weeks), previous infection with virulent field strains of IBDV or infection occurring in the presence of maternal antibody [1].

The most prominent lesions of IBD are found in the bursa of fabricius, hence the name infectious bursa disease (IBD) which is used presently [8,9]. Gross lesions described by Cosgrove [2] included dehydration, haemorrhages on the breast and thigh muscles, hepatic infarction, enlarged kidneys with pronounced tubules, ureters filled with urates and an enlarged bursa. Further findings show that the proventricular mucosa shows haemorrhages, which can occur characteristically as a band at the proventricular-gizzard junction. There is haemorrhagic enteritis and liver appears parboiled. Spleen and thymus enlargement are also seen, but they later become atrophic. Bursa is edematous and enlarged two to three times its normal size by the fourth day, post infection, and the size then begins to recede $[5,10]$. By the $5^{\text {th }}$ day, the bursa returns to normal weight, but it continues to atrophy and from the $8^{\text {th }}$ day forward, it is approximately one-third of its original weight. By the $2^{\text {nd }}$ and $3^{\text {rd }}$ day 
post infection, the bursa has a gelatinous yellowish transudetion covering the serosal surface. The longitudinal striations on surface of the kidneys become prominent and the normal white colour turns to cream colour.

Helmboldt and Garner [11] in experimental IBD reported that the bursa was twice its normal size three days post infection and was oedematous, haemorrhagic and atrophic by 12 days PI. Intramuscular haemorrhages occurred in $1 \%$ of the birds and the spleen was slightly swollen and mottled, with deep red spots.

Lensing [12] and Maire et al. [13] made an additional observation of haemorrhagic lesions in the proventricular papillae. Chineme [14] reported a slight splenic enlargement with small grey foci uniformly dispersed on the surface, while Cho and Edgar [3] described atrophy of the spleen and bursa and hypertrophy of the liver.

These earlier reports of gross lesions of IBD were confirmed by later reports [15-17]. Schobries [18] reported that the skin and heart of infected chicks were also affected by IBD.

There are two distinct serotypes of IBDV, designated as serotypes 1 and 2. Viruses of serotype I are pathogenic to chickens whereas serotype 2 viruses, mostly isolated from turkeys, do not replicate in chicken cells [19]. Even IBDV isolates of same serotype I can differ markedly in their virulence, because, they have different replication efficiency in lymphoid bursa cells [20]. At least six antigenic subtypes of IBDV serotype I have been identified by in vitro cross neutralization assay [21].

Viruses belonging to one antigenic subtype are commonly known as variants. Variants of IBDV serotype 1 have been reported to breakthrough high level maternal antibodies in commercial flocks, causing up to 60 to 70 percent mortality rate in chicken [22]. Some variant strains induce damage in the bursa of fabricious in chickens, even when high and uniform antibody titres of the standard IBDV are present. These variant strains may not cause obvious clinical disease, but induce severe immunosuppression. Bursae of affected chickens undergo rapid atrophy due to lymphocyte depletion. These variants are not from a different serotype, but are anti-genically different enough to cause problems.

McFerran et al. [19] in Northern Ireland were the first to report antigenic variations among IBDV isolates of European origin. They presented evidence of existence of two serotypes, designated, "one” and "two" which showed only $30 \%$ relatedness to each other. Similar findings were reported in the United States of America [23]. The American serotypes were also designated "one" and "two". Later studies by McNulty, et al., [24] revealed relatedness of the European and American serotype "two" isolates. So, use of the Arabic numerals 1 and 2 to describe the two serotypes of IBDV was agreed. Antigenic relatedness of only $33 \%$ between two strains of serotype 2 was reported, indicating antigenic diversity, similar to that of serotype 1 viruses [25].

The two serotypes can be differentiated by virus neutralization test, but they are not distinguishable by fluorescent antibody test or Enzyme-linked Immunosorbent Assay. Immunization against serotype 2 does not protect against serotype 1 . The reverse situation could not be tested, because there are no virulent serotype 2 IBD viruses for challenge [26,27].

The first isolates of serotype 2 originated from turkeys and it was thought that this serotype was host specific [28]. Later studies showed, however, that viruses of serotype 2 could be isolated from chickens [29] and antibodies to serotype 2 IBDV strains are common in both chickens and in turkeys [30,31].

So, two serotypes of IBDV are known to exist and within the serotypes. There are variants. Variant strains of IBDV, which have major antigenic differences from the "standard" strains, cause immunosuppression but do not cause disease in older chickens [32].

Economic importance of IBD stems from heavy morbidity and mortality, reduction in growth rate and immunosuppression, making the birds susceptible to other diseases, such as Newcastle disease [33]. Sequelae of immunosuppression due to IBD include gangrenous dermatitis, inclusion body hepatitis-anaemia syndrome, Escherichia coli infection and vaccination failures [1].

IBD has been reported from every poultry-producing country in the world. First diagnosed in 1962, the causative virus has changed form and has manifested itself in different forms that make it even a bigger threat to the poultry industry [34]. Effectiveness of IBD vaccination depends on the field variants involved. There is therefore need to confirm variants of the IBDV that exist in each locality and the type of disease they cause in poultry. In Europe, very virulent IBDV (VVIBDV) strains which cause mortalities as high as $90 \%-100 \%$ have been reported [35,36]. In Nigeria isolates so far reported cause mortality rates of $43.8 \%$ - 57\% [37].

Apart from mortality rates, antibody titer which protects chicks against IBDV challenge can be used as a measure of virulence of the IBDV variants in the locality. Lukert and Saif [37] reported that passive haemagglutination (PHA) titer of 64 is protective against isolates of IBDV that are in Europe and America. The passive haemagglutination test is among the cheapest, simplest and most rapid serological tests for IBD. It is suited for screening many samples as is required in epidemiologic studies and researches. Modification of the test for measuring viral titers has also been developed [38]. It is therefore necessary to determine passive haemagglutination antibody titer that would protect chicks against Nigerian isolates of the IBDV. 


\section{MATERIALS AND METHODS}

Fifty cockerel chicks were used for the experiment. They were randomly allocated to 5 groups of 10 chicks each. Different vaccination methods were adopted for the groups, to achieve different levels of immunity.

Three weeks post vaccination, 5 chicks from each of the groups were bled and the sera used to measure antibody titer of the groups, by the passive haemagglutination method while the remaining 5 chicks were challenged with a virulent Nigerian isolate of the IBDV (NVRI, Vom, Nigeria) to record mortality rates. Mortality rates of the five groups were plotted against their respective antibody titers. Equation for a line of best fit of the graph was generated by the formula reported by Gujarati [39]. From the equation, antibody titer at which mortality rate was zero, was calculated as Protective antibody titer against the Nigerian isolate of the Infectious Bursa Disease Virus.

\section{RESULTS}

Antibody titers of the vaccinated groups of chicks and their mortality rates following challenge with the virulent Nigerian isolate of IBDV, were as follows: For chicks with Zero antibody titer mortality was $75 \%$. For antibody titers of 185.6, 243.2, 256 and 307 mortality rates were. $40 \%$, Zero\%. Zero\% and Zero\% respectively. The mortality rates and the antibody titers are presented on Figure 1. Equation for relationship between IBD antibody titers and mortality rates resulting from challenge with the Nigerian isolate of the IBDV is: $\mathrm{Y}=75-0.25 \mathrm{X}(\mathrm{Gu}-$ jarati, 2000), where $\mathrm{Y}=$ Mortality rate and $\mathrm{X}=$ Mean PHA antibody titer of the chicks. So, PHA protective antibody titer against the Nigerian IBDV isolate $=300$.

\section{DISCUSSION}

PHA antibody titer that protects chicks against IBDV

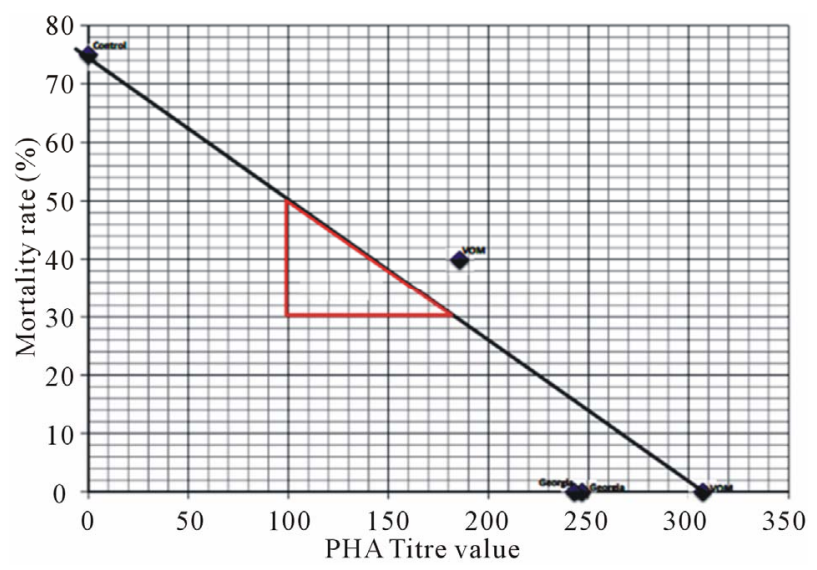

Figure 1. Mortality rates of chicks, with different Passive Hemagglutination antibody titers, challenged with a Nigerian Infectious Bursa Disease Virus isolate. challenge in Europe and America is 64 [37], but in this study with a Nigerian isolate of the virus, protective antibody titer is 300. That hypervirulent variants of the IBDV are circulating in Nigeria has been reported [10]. Hypervirulence of the Nigerian IBDV isolates may be responsible for the higher antibody titer required to protect chicks against it.

IBDV variants, different from the "standard" strains, cause immunosuppression but not clinical disease in chickens immunized against the standard IBDV [32]. Mortalities in IBD have also been reported to vary from country to country, depending on variants of the virus in circulation. Strains of very virulent IBDV reported from Europe cause mortality rates of up to $90 \%$ [35] or even $100 \%$ [36]. Earlier studies with Nigerian isolates gave mortality rates of $43.8 \%$ [37] and 57\% [38]. So, a mortality of $75 \%$ observed in the group of unvaccinated chicks in this study shows a significant increase from the earlier reports. It suggests that the hypervirulent Infectious bursa disease virus may be present in Nigeria.

Effectiveness of vaccinations to control IBD is dependent on variants of the virus in circulation in the area. Variants of IBDV of same serotype 1 have been reported to break through high levels of maternal antibodies in commercial flocks vaccinated with vaccines made from different variants, causing up to $60 \%$ to $70 \%$ mortality [22]. Some variants induce damage in the bursa of fabricious in chickens, even when high and uniform antibody titers from vaccination with vaccines of a different variant are present. Such challenge strains may not cause obvious clinical disease, but they could induce severe immunosupression. To prevent both the high mortality of chicks due to IBD and immunosupression due to silent IBDV infections in Nigerian poultry flocks, vaccines being used in the country should be those made from strains of the virus circulating in Nigeria. The vaccines and vaccination methods should also be such to achieve at least PHA titer 300 which is equivalent of 512 in serial double dilutions.

\section{REFERENCES}

[1] Chou, K.C. and Calnek, B.W. (1997) Diseases of poultry, Iowa state university press. 10th Edition, Ames, Iowa 721-733.

[2] Cosgrove, A.S. (1962) An apparently new disease of chickens-Avian nephrosis. Avian Disease, 6, 385-389. doi:10.2307/1587909

[3] Cho, Y. and Edgar, S.A. (1969) Characterisation of the infectious bursal agent. Poult. Science, 48, 2102-2109. doi:10.3382/ps.0482102

[4] United Kingdom Epidermiological unit, central vet. Lab (1981) Subclinical infectious bursal disease in broiler industry. Interim report. Veterinary Record, 108, 88-89.

[5] Okoye, J.O.A. and Uzoukwu, M. (1981) An outbreak of 
infectious bursal disease among Chickens between 16 and 20 week old. Avian Disease, 25, 1034-1038. doi:10.2307/1590079

[6] Okoye, J.O.A. (1983) The pathogenecity and pathology of a Nigerian isolate of infectious bursal disease virus in chickens. M. Phil. Diss., University of Nigeria, Nsukka.

[7] Okoye, J.O.A. and Soyinka, S.V.O. (1983) Newcastle disease in a vaccinated flock which had experienced subclinical infections bursal disease. Tropical Animal Health and Production, 15, 221-225. doi:10.1007/BF02242062

[8] Muller, H. (1986) Replication of infectious bursal disease virus in lymphoid cells. Archives of Virology, 87, 191-203. doi:10.1007/BF01315299

[9] Mcllroy, S.G., Goodall, D.W., Bruce, D.W., McCracken, R.M. and McNulty, M.S. (1992) The cost benefit of vaccinating broiler flocks against subclinical infectious bursal disease. Avian Pathology, 21, 65-76. doi:10.1080/03079459208418819

[10] Okoye, J.O.A. and Aba-Adulugba, E.P. (1998) Comparative study of the resistance or susceptibility of local Nigerian chicken and exotic chickens to Infectious bursal Disease. Avian Pathology, 27, 168-173. doi:10.1080/03079459808419319

[11] Helmbolt, C.F. and Garner, E. (1964) Experimentally induced Gumboro disease (IBA). Avian Disease, 8, 561575. doi:10.2307/1587944

[12] Lensing, H.H (1968) Gumboro disease. Tijdschr. Diergeneesk, 93, 1452-1460.

[13] Maire, C., Renault, L., Alamagny, A., Dreuille, M.D.E. and Albouy, R. (1969) Existence en France de la maladie de Gumboro. Rec med. Vet, 145, 75-84.

[14] Chineme, C.N. (1977) Clinicopathologic and morphologic changes in experimental infectious bursal (Gumboro) disease. Abstracts of papers presented at the $14^{\text {th }}$ Annual conference of the Nigerian Veterinary Medical Association. Journal of Nigerian Veterinary Medical Association, 61, 46.

[15] Hirai, K.K., Kunihiro and Shimakura, S. (1979) Characterization of immunosuppressionin chickens by infectious bursal disease virus. Avian Disease, 23, 950-965. doi:10.2307/1589611

[16] Delegation of the United States of America (1977) Infectious bursal disease (Gumbro) Field incidence in the United States. Bulletin de l Office International des Epizooties, 88, 313-322.

[17] Gyening, K.O. and Corkish, J.D. (1977) Infectious bursal disease in Ghana. Bulletin de l Office International des Epizooties, 88, 293-298.

[18] Schobries, H.D., Wilke, I. and Schmidt, V. (1977) Infektiose Bursitis (Gumboro disease) in einem Broiler-bestand. Veterinary Medicine, 32, 700-704.

[19] Mcferran, J.B., McNulty, M.S., Mckillop, E.R., Conner, T.J., McCracken, R.M., Collins, D.S. and Allan G.M. (1980) Isolation and serological studies with infectious bursal disease viruses from fowl, turkey and duck: Demonstration of a second serotype. Avian Pathology, 9, 395404. doi:10.1080/03079458008418423

[20] Tsukamoto, K., Tanimura, N., Kakita, S., Ota, K., Mase, M.,
Imai, K. and Hihara, H. (1995) Efficacy of three live vaccines against highly virulent infections bursal disease virus in chickens with or without maternal antibodies. Avian Disease, 39, 218-229. doi:10.2307/1591863

[21] Jackwood, D.J. and Saif, Y.M. (1983) Prevalence of antibodies to infectious bursal disease virus serotypes I and II in 75 Ohio Chicken. Avian Disease, 27, 850-854. doi: $10.2307 / 1590331$

[22] Etterradossi, N. (2001) Major advances in infectious bursal disease virus (IBV) research seen the first international IBDV/.CIAV symposium (Rauischholzhausen, Germany, 1994) Proceeding of II International symposium on infectious bursal disease and Chicken Infectious Anaemia, Rauischholzhausen, 16-20 July 2001, 6-23.

[23] Jackwood, D.J., Saif, Y.M. and Hughes, J.H. (1982) Characteristics and serological studies of two serotypes of infectious bursal disease virus in turkeys. Avian Disease, 26, 871-882. doi:10.2307/1589875

[24] Mcferran, J.B., McNulty, M.S., Mckillop, E.R., Conner, T.J., McCracken, R.M., Collins, D.S. and Allan, G.M. (1980) Isolation and serological studies with infectious bursal disease viruses from fowl, turkey and duck: Demonstration of a second serotype. Avian Pathology, 9, 395-404. doi:10.1080/03079458008418423

[25] Jackwood, D.J., Saif, Y.M. and Moorhead, P.D. (1985) Immunogenicity of infectious bursal disease virus serotypes I and II IN chickens. Avian Disease, 29, 1184-1194. doi:10.2307/1590472

[26] Ismail, N., Saif, Y.M. and Moorhead, P.D. (1988) Lack of pathogenicity of five serotype 2 infectious bursal disease viruses in chickens. Avian Disease, 32, 757-759. doi:10.2307/1590995

[27] Jackwood, D.J., Saif, Y.M. and Hughes, J.H. (1982) Characteristics and serological studies of two serotypes of infectious bursal disease virus in turkeys. Avian Disease, 26, 871-882. doi:10.2307/1589875

[28] Ismail, N.M., Saif, Y.M., Wigle, W.L., Havenstein G.B. and Jackson, C. (1990) Infectious bursal disease virus variant from commercial Leghorn pullets. Avian Disease, 34, 141145.

[29] Jackwood, D.J., Saif, Y.M. and Moorhead, P.D. (1985) Immunogenicity of infectious bursal disease virus serotypes I and II IN chickens. Avian Disease, 29, 1184-1194. doi: $10.2307 / 1590472$

[30] Saif, Y.M. (1984) Infectious bursal disease virus types in Proceedings of 19th National Meeting of Poult Heaith Condemn, Ocean City, 105-107.

[31] Cynthia (2005) Infectious bursal disease (Gumbro disase), Merck veterinary mammal, Merck \& Co., Inc., White House Station, 2248-2253.

[32] Shome, B.R., Shome, R., Snvastava, N. and Bandy, A.K. (1997) Infectious bursal disease in the Andamas: Isolation and identification of the virus. Indian Veterinary Journal, 74, 281-283.

[33] Cereno, T.N. (2008) Infectious Bursal Disease (IBD): Causative agent, diagnosis and prevention. http://www.canadianpoultryca./infectious_bursal_disease. htm 
[34] Chettle, N.J.C., Stuart and Wyeth, P.J. (1989) Outbreak of virulent infectious bursal disease in East Anglia. Veterinary Record, 125, 271-272. doi:10.1136/vr.125.10.271

[35] Vanden Berg, T.P. and Meulemans, G. (1991) Acute infectious bursal disease in poultry: protection afforded by maternally derived antibodies and interference with live vaccination. Avian Pathology, 20, 409-421. doi:10.1080/03079459108418779

[36] Onunkwo, O. (1975) Problems of gumboro disease of chickens in Nigeria. Journal of Nigeria Poultry Science, 2, 95-101.

[37] Lukert, P.D. and Saif, Y.M. (2003) Infectious bursal dis- ease. In Saif, Y.M., Glisson, J.R., Fadly, A.M., McDougald, L.R. and Swayne, D.E. (Eds.), Diseases of Poultry, 11th Edition, Iowa State University Press, Ames, 161180.

[38] Ezeibe, M.C.O., Okoye, J.O.A., Ogunniran, T.M., Okoroafor, O.N., Ezeala, I.E. and Ngene, A.A. (2012) Modification of the passive heamagglutination test for detection of infectious bursal disease virus. Health, 4, 653-655. doi:10.4236/health.2012.49102

[39] Gujarati, D.N (2000) Basic econometrics. 4th Edition, McGrahill Publishers, New York. 